\title{
ANALISIS LAPORAN ARUS KAS UNTUK MENILAI KINERJA KEUANGAN PERUSAHAAN MAKANAN DAN MINUMAN YANG TERDAFTAR DI BURSA EFEK INDONESIA
}

\author{
Trisilia Kaloh ${ }^{1}$, Ventje Ilat ${ }^{2}$, Sonny Pangerapan ${ }^{3}$ \\ 1,2,3 Jurusan Akuntansi, Fakultas Ekonomi dan Bisnis, Universitas Sam Ratulangi, Jl. Kampus Bahu, Manado \\ 95115, Indonesia \\ Email : kalohchicy@gmail.com
}

\begin{abstract}
A necessity for companies to include cash flow statements in financial statements. One analysis of financial performance using the cash flow statement is the ratio of cash flow statements. The purpose of this study was to find out the financial performance of six food and beverage companies during 2014-2017. This study uses the ratio analysis method. The ratio used in this study is the ratio of operating cash flows, the ratio of operating cash flow to interest, the ratio of capital expenditure, the ratio of total debt, and the ratio of cash flows to net income. From the results of calculations using the ratio analysis of cash flow reports obtained that from the six food and beverage companies namely PT. Tiga Pilar Sejahtera Food Tbk, PT. Delta Djakarta Tbk, PT. Mayora Indah Tbk, PT. Nippon Indosari Corpindo Tbk, PT. UltraJaya Milk Industry \& Trading Company Tbk, PT. Indofood Sukses Makmur Tbk has a very good improvement, although not too high.
\end{abstract}

Keywords: Cash flow statement, Operating cash flow, Cash flow ratio, Financial performance, Bursa Efek Indonesia.

\section{PENDAHULUAN}

Perkembangan industri makanan dan minuman di Indonesia semakin pesat. Industri makanan dan minuman mendapat peluang yang lebih besar untuk terus berkembang. Salah satu alasan dilakukan analisis laporan keuangan adalah untuk menilai kinerja keuangan perusahaan. Bursa Efek Indonesia (BEI) merupakan salah satu Bursa Efek yang cepat perkembangannya sehingga menjadi alternatif yang disukai perusahaan go public yang mencari dana. Dalam laporan keuangan salah satu instrument yang tepat untuk dipelajari dalam mengevaluasi dan mengukur kinerja keuangan perusahaan, karena dalam nya terdapat informasi yang penting meliputi informasi keuangan tentang hasil usaha maupun posisi financial dari perusahaan tersebut.Salah satu alasan dilakukan analisis laporan keuangan adalah untuk menilai kinerja keuangan perusahaan.

\section{TINJAUAN PUSTAKA}

Pengertian Akuntansi. Menurut Pontoh (2013:1), menyatakan bahwa akuntansi adalah sebuah sistem informasi yang mengukur aktivitas bisnis, pemrosesan data menjadi laporan, dan mengkomunikasikan hasilnya pada para pengambil keputusan. Akuntansi adalah sebuah sistem informasi yang menyediakan laporan-laporan kepada para pengguna mengenai aktivitas ekonomi dan kondisi bisnis-bisnis yang ada. Akuntansi meliputi 3 (tiga) aktivitas dasar identifikasi, pencatatan, dan mengkomunikasikan peristiwa ekonomi dari sebuah organisasi kepada para pengguna yang berkepentingan. Akuntansi adalah sebuah sistem informasi yang dirancang oleh sebuah organisasi untuk mengidentifikasi (analisis, pencatatan, dan meringkas) aktivitas-aktivitas yang mempengaruhi kondisi dan kinerja keuangannya, kemudian mengkomunikasikan hasilnya kepada para pengambil keputusan, baik dari internal maupun eksternal organisasi. Menurut Hans Kartikahadi (2016:3), 
menyatakan bahwa akuntansi adalah suatu sistem informasi keuangan, yang bertujuan untuk menghasilkan dan melaporkan informasi yang relevan bagi berbagai pihak yang berkepentingan.

Kinerja Keuangan. Menurut Rudianto (2013:189), menyatakan bahwa kinerja keuangan adalah hasil atau prestasi yang telah dicapai oleh manajemen perusahaan dalam mengelola aset perusahaan secara efektif selama periode tertentu. Kinerja keuangan sangat dibutuhkan oleh perusahaan untuk mengetahui dan mengevaluasi tingkat keberhasilan perusahaan berdasarkan aktivitas keuangan yang telah dilaksanakan. Penilaian setiap perusahaan adalah berbeda-beda karena ruang lingkup bisnis dijalankan. Jika perusahaan tersebut bergerak pada bidang pertambangan maka itu beda dengan perusahaan yang bergerak di bidang pertanian. Begitu juga dengan sektor keuangan seperti perbankan yang jelas memiliki ruang lingkup yang berbeda dengan ruang lingkup bisnis lainnya". Menurut Fahmi (2012:2) menyatakan bahwa "kinerja keuangan adalah suatu analisis yang dilakukan untuk melihat sejauh mana perusahaan telah melaksanakan dengan menggunakan aturanaturan pelaksanaan keuangan secara baik dan benar seperti dalam membuat suatu laporan keuangan yang telah memenuhi standar atau ketentuan dalam PSAK atau GAAP dan lainlainnya.

Pengertian Kas dan Setara Kas. Menurut Subramanyam (2017:249), menyatakan bahwa kas (cash) merupakan aset yang paling likuid, mencakup mata uang yang tersedia dan dana pada deposito. Setara kas (cash equivalent) merupakan investasi jangka pendek yang sangat likuid yang mudah dikonversi menjadi kas dan jatuh tempo sangat pendek, sehingga memiliki risiko minimal terkait perubahan harga akibat pergerakan suku bunga. Investasi ini biasanya memiliki jatuh tempo tiga bulan atau lebih pendek. Kas dapat dikatakan merupakan satu-satunya pos yang paling penting dalam neraca. Karena berlaku sebagai alat tukar secara langsung atau tidak langsung dalam hampir semua transaksi usaha. Hal ini sesuai dengan sifat-sifat kas yaitu:

1. Kas terlalu terlibat dalam hampir semua transaksi.

2. Kas merupakan harta yang siap dan muda untuk digunakan dalam transaksi serta ditukarkan dengan harta lain, mudah dipindahkan dan beragam tanpa tanda pemilik.

3. Jumlah uang kas yang dimiliki oleh perusahaan harus dijaga sedemikian rupa sehingga tidak terlalu banyak dan tidak kurang.

Menurut Dwi (2015:30), menyatakan bahwa kas merupakan konsep yang paling berguna, karena keputusan para investor, kreditor, dan pihak lain yang terfokus pada penilaian arus kas di masa datang. Perusahaan akan memanfaatkan kas menganggur dengan menanamkannya pada investasi jangka pendek yang sangat likuid. Kas terdiri atas saldo kas (cash on hand) dan kas yang ada di bank dalam bentuk rekening koran atau giro (cash in bank). Setara kas (cash equivalent) adalah investasi yang sifatnya sangat likuid, berjangka pendek dan yang dengan cepat dapat dijadikan kas dalam jumlah tertentu tanpa menghadapi risiko perubahan nilai yang signifikan. Sedangkan arus kas (cash flow) adalah arus masuk (inflow) dan arus keluar (outflow) kas dan setara kas. Arus kas tidak mencakup mutasi di antara pos-pos yang termasuk dalam kas dan setara kas. Setara kas biasanya memiliki tujuan untuk memenuhi komitmen jangka pendek dan bukan untuk investasi atau tujuan lain. Suatu investasi baru dapat memenuhi syarat sebagai setara kas jika segera akan jatuh tempo dalam waktu tiga bulan atau kurang dari tanggal perolehannya.

Pengertian Laporan Keuangan. Menurut Subramanyam (2017:4), menyatakan bahwa laporan keuangan merupakan bagian dari analisis bisnis. Analisis bisnis merupakan evaluasi atas prospek dan risiko perusahaan untuk pengambilan keputusan bisnis. Laporan keuangan adalah suatu laporan (financial statement) akan menjadi lebih bermanfaat untuk pengambilan keputusan, apabila dengan informasi laporan keuangan tersebut dapat diprediksi apa yang akan terjadi di masa mendatang. Menurut Mamduh Hanafi dan Abdul Halim 
(2016:35), menyatakan bahwa laporan keuangan merupakan salah satu sumber informasi yang penting di samping informasi lain seperti industri, kondisi perekonomian, pangsa pasar perusahaan, kualitas manajemen dan lainnya. Menurut Dwi Prastowo (2015:3), menyatakan bahwa tujuan laporan keuangan untuk menyediakan informasi yang menyangkut posisi keuangan, kinerja, dan perubahan posisi keuangan suatu perusahaan yang bermanfaat bagi sejumlah besar pemakai dalam pengambilan keputusan ekonomi. Informasi mengenai posisi keuangan, kinerja dan perubahan posisi keuangan sangat diperlukan untuk dapat melakukan evaluasi atas kemampuan perusahaan dalam menghasilkan kas (dan setara kas), dan waktu serta kepastian dari hasil tersebut. Posisi keuangan perusahaan dipengaruhi oleh sumber daya yang dikendalikan, struktur keuangan, likuiditas, dan solvabilitas serta kemampuan beradaptasi perubahan lingkungan. Menurut Ikatan Akuntan Indonesia (IAI) dalam PSAK No.2 (2015), tujuan laporan keuangan yaitu memberikan informasi mengenai posisi keuangan kinerja keuangan dan juga arus kas entitas yang bermanfaat bagi sebagian besar kalangan pengguna laporan dalam pembuatan keputusan ekonomi”.

Jenis- Jenis Laporan Keuangan. Menurut PSAK No.2 (2015), terdiri dari:

1. Laporan posisi keuangan pada akhir periode.

2. Laporan laba rugi dan penghasilan komprehensif lain selama periode.

3. Laporan perubahan ekuitas selama periode.

4. Laporan arus kas selama periode.

5. Catatan atas laporan keuangan, berisi ringkasan kebijakan akuntansi yang signifikan dan informasi penjelasan lain.

6. Laporan posisi keuangan pada awal periode terdekat sebelumnya ketika entitas menerapkan suatu kebijakan akuntansi secara retrospektif atau membuat penyajian kembali pos-pos laporan keuangan, atau ketika entitas mereklasifikasi pos-pos dalam laporan keuangannya sesuai dengan paragraf 40A-40D.

Menurut Kasmir (2014:9), secara umum ada 5 (lima) jenis laporan keuangan yang biasa disusun, yaitu: Balance Sheet (Neraca), Income Statement (Laporan Laba Rugi), Laporan Perubahan Modal, Laporan Arus Kas, dan Laporan Catatan Atas Laporan Keuangan.

Pengertian Laporan Arus Kas. Menurut Warren et al. (2014:726), menyatakan bahwa laporan arus kas adalah "the primary purpose of the statement of cash flow is to provide relevant information about the cash receipts and cash payment of an enterprise during a period". Menurut Mamduh Hanafi dan Abdul Halim (2016:58), menyatakan bahwa laporan arus kas hanya menerbitkan neraca dan laporan laba rugi. Laporan arus kas menunjukkan perubahan posisi nilai kas yang berasal dari aktivitas operasi, investasi, dan pendanaan sebagai akibat adanya transaksi-transaksi yang dilakukan oleh perusahaan selama satu periode tertentu dan laporan arus kas memberikan informasi mengenai arus kas masuk dan arus kas keluar perusahaan.

Tujuan Laporan Arus Kas. Menurut Mamduh Hanafi dan Abdul Halim (2016:58), menyatakan bahwa satu-satunya tujuan laporan keuangan adalah untuk memberikan informasi mengenai aliran dana perusahaan. Laporan arus kas bermanfaat untuk mencapai tujuan ini lebih jauh lagi, laporan keuangan diharapkan bisa memberi informasi mengenai likuiditas perusahaan, fleksibilitas keuangan perusahaan, dan kemampuan operasional perusahaan. Menurut Ikatan Akuntan Indonesia (IAI) dalam PSAK No.2 (2015), tujuan laporan keuangan adalah memberikan informasi mengenai posisi keuangan, kinerja keuangan, dan arus kas besar kalangan pengguna laporan keuangan dalam pembuatan keputusan ekonomi. Laporan keuangan juga menunjukkan hasil pertanggungjawaban manajemen atas penggunaan sumber daya yang dipercayakan kepada mereka.

Manfaat Laporan Arus Kas. Menurut Hery (2016:88), menyatakan bahwa laporan arus kas digunakan oleh manajemen untuk mengevaluasi kegiatan operasional yang telah berlangsung dan merencanakan aktivitas investasi dan pembiayaan di masa yang akan datang. 
Laporan arus kas juga digunakan oleh kreditor dan investor dalam menilai tingkat likuiditas maupun potensi perusahaan dalam menghasilkan laba. Menurut Sofyan Syafri Harapan (2015:257), menyatakan bahwa manfaat laporan arus kas adalah sebagai berikut:

1. Kemampuan perusahaan meng"generate" kas, merencanakan, mengontrol arus kas masuk dan arus kas keluar perusahaan pada masa lalu.

2. Kemungkinan arus kas masuk dan keluar, arus kas bersih perusahaan, termasuk kemampuan membayar deviden di masa yang akan datang.

3. Informasi bagi investor dan kreditor untuk memproyeksikan return dari sumber kekayaan perusahaan.

4. Kemampuan perusahaan untuk memasukan kas ke perusahaan di masa yang akan datang.

5. Alasan perbedaan antara laba bersih dibandingkan dengan penerimaan dan pengeluaran kas.

6. Pengaruh investasi baik kas maupun bukan kas dan transaksi lainnya terhadap posisi keuangan perusahaan selama satu periode tertentu.

\section{Klasifikasi Laporan Arus Kas}

1. Aktivitas Kas dari Aktivitas Operasi. Menurut Warren et al. (2014:727), menyatakan bahwa: "cash flows from operating activities reports the cash inflows and outflows from a company's day to day operations".

2. Arus Kas dari Aktivitas Investasi. Menurut Warren et al. (2014:728), mengungkapkan bahwa: "cash flows from investing activities show the cash inflows and outflows related to changes in company's long term assets".

3. Arus Kas Dari Aktivitas Pendanaan. Menurut Warren et al. (2014:729), menyatakan bahwa: "cash flows from financing activities show the inflows and outflows related to changes in copany's long term liabilities and stockholder's equity'.

Menurut Dwi Prastowo (2015:30), menyatakan bahwa laporan arus kas harus melaporkan arus kas selama periode tertentu dan harus mengklasifikasikan arus kas tersebut menurut aktivitas operasi (operating activities), investasi (investing activities), dan pendanaan (financing activities). Penyajian kas menurut ketiga klasifikasi tersebut dilakukan dengan cara yang paling sesuai dengan karakteristik bisnis suatu perusahaan.

Pelaporan Arus Kas. Menurut PSAK No.2 (2015), dalam metode ini pelaporan arus kas dilakukan dengan cara melaporkan kelompok-kelompok penerimaan kas dan pengeluaran kas dari kegiatan operasi secara lengkap dan baru dilanjutkan dengan kegiatan investasi dan pembiayaan. Terdapat dua metode penyajian alternatif pelaporan arus kas dari aktivitas operasi dalam laporan arus kas yaitu:

a. Metode langsung, dengan metode ini kelompok utama dari penerimaan kas bruto dan pengeluaran kas bruto diungkapkan.

b. Metode tidak langsung, dengan metode ini laba atau rugi bersih disesuaikan dengan mengoreksi pengaruh dari transaksi bukan kas, penangguhan (deferral) atau akrual dari penerimaan atau pembayaran kas untuk operasi di masa lalu dan di masa depan, unsur penghasilan atau beban yang berkaitan dengan arus kas investasi atau pendanaan.

Namun dalam PSAK No.2 (2015), menganjurkan agar perusahaan melaporkan arus kas operasi ini dengan menggunakan metode langsung. Metode ini menghasilkan informasi yang berguna dalam mengestimasi arus kas masa depan yang tidak dapat dihasilkan dengan metode tidak langsung. Dengan metode langsung informasi mengenai kelompok untuk penerimaan kas bruto dan pengeluaran kas bruto dapat diperoleh dari catatan akuntansi perusahaan, atau penyesuaian penjualan, beban pokok penjualan, dan pos-pos lain dalam laporan laba rugi untuk:

1. Perubahan persediaan, piutang usaha, dan utang usaha selama periode berjalan.

2. Pos bukan kas lainnya. 
3. Pos lain yang berkaitan dengan arus kas investasi dan pendanaan.

Dengan metode tidak langsung, arus kas bersih dari aktivitas operasi ditentukan dengan laba atau rugi bersih dari pengaruh:

1. Perubahan persediaan dan piutang usaha serta utang usaha selama periode berjalan.

2. Pos bukan kas seperti penyusutan, penyisihan, pajak ditangguhkan, keuntungan dan kerugian valuta asing yang belum direalisasi, laba perusahaan asosiasi yang belum dibagikan, serta hak minoritas dalam laba atau rugi konsolidasi.

3. Semua pos lain yang berkaitan dengan arus kas investasi atau pendanaan. Sebagai alternatif, berdasarkan arus kas bersih dari aktivitas operasi dapat dilaporkan (tidak langsung) dengan menyajikan pendapatan dan beban yang diungkapkan dalam laporan laba rugi serta perubahan dalam persediaan, piutang usaha, dan utang usaha selama periode.

Menilai Kinerja Laporan Arus Kas. Menurut Hery (2015:124), menyatakan bahwa analisis laporan arus kas merupakan analisis finansial yang sangat penting bagi seorang manajemen keuangan suatu perusahaan di samping alat-alat finansial lainnya, dengan melakukan analisis laporan arus kas, manajer keuangan dapat melaksanakan salah satu fungsinya yaitu fungsi perencanaan. Salah satu analisis keuangan dengan menggunakan informasi laporan arus kas adalah analisis laporan arus kas dan komponen neraca dan laporan laba rugi sebagai informasi dalam analisis rasio.

Penelitian Terdahulu. Rando Bawelle (2016), analisis arus kas bersih operasi sebagai alat ukur kinerja keuangan pada industri rokok di Bursa Efek Indonesia. Hasil penelitian yang diperoleh dari penelitian ini adalah rasio diperoleh bahwa selama tahun 20122014 mempunyai kinerja keuangan yang terbaik. Susanti Tudje (2017), analisis laporan arus kas sebagai alat ukur kinerja keuangan pada perusahaan Consumer Goods Industry di Bursa Efek Indonesia. Hasil penelitian menggunakan rasio diperoleh bahwa selama tahun 20122015 kinerja keuangan belum maksimal karena tidak mencapai standar rasio.

\section{METODE PENELITIAN}

Jenis Penelitian. Menurut Sugiyono (2015:220), dalam penelitian ini penulis menggunakan jenis penelitian deskriptif kualitatif. Penelitian ini mengambil data perusahaan makanan dan minuman yang terdaftar di Bursa Efek Indonesia cabang Manado.

Tempat dan Waktu Penelitian. Dalam penelitian ini yang menjadi objek penelitian adalah perusahaan makanan dan minuman yang terdaftar di Bursa Efek Indonesia tahun 2014-2017. Adapun waktu penelitian selama bulan September 2018.

\section{Populasi dan Sampel}

a. Populasi dalam penelitian ini adalah laporan keuangan di perusahaan makanan dan minuman yang listed di Bursa Efek Indonesia selama kurun waktu 4 (empat) tahun, periode 2014-2017. Perusahaan makanan dan minuman merupakan salah satu jenis perusahaan yang tidak terpengaruh secara signifikan oleh dampak krisis global, selain itu tingkat konsumsi masyarakat terhadap barang yang dihasilkan dalam industri tersebut sudah menjadi kebutuhan dan relatif tidak berubah, baik kondisi perekonomian membaik maupun memburuk. Jumlah populasi dalam penelitian ini ada 6 (enam) perusahaan.

b. Sampel adalah bagian dari jumlah karakteristik yang dimiliki oleh populasi tersebut. Teknik pengambilan sampel dalam penelitian ini dilakukan secara purpositive sampling, yaitu metode penetapan sampel dengan didasarkan kriteria-kriteria tersebut. Kriteria yang digunakan untuk memilih sampel adalah sebagai berikut:

1. Terdaftar di Bursa Efek Indonesia selama periode 2014-2017.

2. Perusahaan yang memiliki data laporan keuangan yang lengkap selama periode penelitian, yaitu 2014-2017.

3. Data dan laporan keuangan yang telah diaudit. 
Jenis dan Sumber Data. Dalam menganalisis penulis menggunakan jenis penelitian deskriptif kualitatif yaitu mengumpulkan data, disusun, diinterpresentasikan dan dianalisis sehingga memberikan kesimpulan yang jelas dan objektif terhadap masalah yang ada, yaitu mengenai laporan arus kas untuk menilai kinerja keuangan perusahaan pada perusahaan makanan dan minuman yang terdaftar di Bursa Efek Indonesia secara keseluruhan dari tahun 2014-2017. Dalam menganalisis penulis menggunakan rasio-rasio arus kas seperti : Rasio Arus Kas Operasi, Rasio Arus Kas Operasi Terhadap Bunga, Rasio Pengeluaran Modal, Rasio Total Hutang, dan Rasio Arus Kas terhadap Laba Bersih.

Teknik Analisis Data. Teknik analisis data yang digunakan dalam penelitian ini adalah dengan menggunakan analisis rasio arus kas. Adapun rasio-rasio yang digunakan dalam penelitian ini adalah:

1. Rasio Arus Kas Operasi. Rasio ini digunakan untuk menghitung kemampuan arus kas operasi dalam membayar kewajiban lancar. Rasio ini diperoleh dengan membagi arus kas operasi dengan kewajiban lancar.

$$
\text { Rasio Arus Kas Operasi }=\frac{\text { Arus Kas Operasi }}{\text { Kewajiban Lancar }}
$$

2. Rasio Arus Kas Operasi terhadap Bunga. Rasio ini digunakan untuk memenuhi kemampuan perusahaan dalam membayar bunga atau hutang yang telah ada. Rasio ini diperoleh dengan arus kas dari operasi tambahan pembayaran bunga, dan pembayaran pajak dibagi bunga.

Rasio Arus Kas Operasi terhadap Bunga $=\frac{\text { Arus Kas Operasi }+ \text { Bunga }+ \text { Pajak }}{\text { Pembayaran Bunga }}$

3. Rasio Pengeluaran Modal. Rasio ini digunakan untuk mengukur modal tersedia untuk investasi dan pembayaran hutang yang ada. Rasio ini diperoleh dengan arus kas operasi dibagi dengan pengeluaran modal.

$$
\text { Rasio Pengeluaran Modal }=\frac{\text { Arus Kas Operasi }}{\text { Pengeluaran Modal }}
$$

4. Rasio Total Hutang. Rasio ini digunakan untuk menunjukkan jangka waktu pembayaran hutang oleh perusahaan dengan asumsi semua arus kas operasi digunakan untuk membayar hutang. Rasio ini diperoleh dari arus kas operasi dibagi dengan total hutang.

$$
\text { Rasio Total Hutang }=\frac{\text { Arus Kas Operasi }}{\text { Total Hutang }}
$$

5. Rasio Arus Kas terhadap Laba Bersih. Rasio ini digunakan untuk menunjukkan seberapa jauh penyesuaian dan asumsi akuntansi akrual mempengaruhi perhitungan laba bersih. Rasio ini dihitung sebagai hasil antara arus kas operasi laba bersih.

$$
\text { Rasio Arus Kas terhadap Laba Bersih }=\frac{\text { Arus Kas Operasi }}{\text { Laba Bersih }}
$$




\section{HASIL DAN PEMBAHASAN}

\subsection{Hasil Penelitian}

$$
\text { Rasio Arus Kas Operasi }=\frac{\text { Arus Kas Operasi }}{\text { Kewajiban Lancar }}
$$

PT. Tiga Pilar Sejahtera Food Tbk (AISA)

Tahun 2014

$$
\text { Rasio Arus Kas Operasi }=\frac{269.394}{1.493 .308}=0,18
$$

Tahun 2015

$$
\text { Rasio Arus Kas Operasi }=\frac{220.650}{2.750 .456}=0,08
$$

Tahun 2016

$$
\text { Rasio Arus Kas Operasi }=\frac{2 \cdot 601.773}{2 \cdot 504.330}=1,04
$$

Tahun 2017

$$
\text { Rasio Arus Kas Operasi }=\frac{3 \cdot 594 \cdot 119}{3 \cdot 902 \cdot 778}=0,92
$$

Tabel 1. Rasio Arus Kas Operasi PT. Tiga Pilar Sejahtera Food Tbk (AISA)

\begin{tabular}{cccc}
\hline Tahun & Arus Kas Operasi & Kewajiban Lancar & Perputaran \\
\hline 2014 & 269.394 & 1.493 .308 & 0,18 \\
2015 & 220.650 & 2.750 .456 & 0,08 \\
2016 & 2.601 .773 & 2.504 .330 & 1,04 \\
2017 & 3.594 .119 & 3.902 .778 & 0,92 \\
\hline
\end{tabular}

Sumber: Data Olahan 2018

$$
\text { Rasio Arus Kas Operasi terhadap Bunga }=\frac{\text { Arus Kas Operasi }+ \text { Bunga }+ \text { Pajak }}{\text { Pembayaran Bunga }}
$$

PT. Mayora Indah Tbk (MYOR)

Tahun 2014

$$
\text { Rasio Arus Kas Operasi terhadap Bunga }=\frac{2.063 .298+361.596+119.876}{361.596}=7,03
$$

Tahun 2015

$$
\text { Rasio Arus Kas Operasi terhadap Bunga }=\frac{488.044+222.126+390.262}{222.126}=4,95
$$

Tahun 2016

$$
\text { Rasio Arus Kas Operasi terhadap Bunga }=\frac{1.610 .711+469.559+457.007}{469.559}=5,40
$$


Tahun 2017

Rasio Arus Kas Operasi terhadap Bunga $=\frac{2.321 .509+273.675+555.931}{273.675}=11,51$

Tabel 2. Rasio Arus Kas Operasi Terhadap Bunga PT. Mayora Indah Tbk (MYOR)

\begin{tabular}{ccccc}
\hline Tahun & $\begin{array}{c}\text { Arus Kas } \\
\text { Operasi }\end{array}$ & Pembayaran Bunga & Pembayaran pajak & Perputaran \\
\hline 2014 & 2.063 .298 & 361.596 & 119.876 & 7,03 \\
2015 & 488.044 & 222.126 & 390.262 & 4,95 \\
2016 & 1.610 .711 & 469.559 & 457.007 & 5,40 \\
2017 & 2.321 .509 & 273.675 & 555.931 & 11,51 \\
\hline
\end{tabular}

Sumber: Data Olahan 2018

$$
\text { Rasio Pengeluaran Modal }=\frac{\text { Arus Kas Operasi }}{\text { Pengeluaran Modal }}
$$

Tahun 2014

$$
\text { Rasio Pengeluaran Modal }=\frac{67.592}{113.596}=0,59
$$

Tahun 2015

$$
\text { Rasio Pengeluaran Modal }=\frac{1 \cdot 074.279}{105.314}=10,2
$$

Tahun 2016

$$
\text { Rasio Pengeluaran Modal }=\frac{241.649}{241.649}=2,51
$$

Tahun 2017

$$
\text { Rasio Pengeluaran Modal }=\frac{260.213}{89.979}=2,89
$$

Tabel 3. Rasio Pengeluaran Modal PT. Delta Djakarta Tbk (DLTA)

\begin{tabular}{cccc}
\hline Tahun & Arus Kas Operasi & Pengeluaran Modal & Perputaran \\
\hline 2014 & 67.592 & 113.596 & 0,59 \\
2015 & 1.074 .279 & 105.314 & 10,2 \\
2016 & 241.649 & 96.275 & 2,51 \\
2017 & 260.213 & 89.979 & 2,89 \\
\hline
\end{tabular}

Sumber: Data Olahan 2018

$$
\text { Rasio Total Hutang }=\frac{\text { Arus Kas Operasi }}{\text { Total Hutang }}
$$

Tahun 2014

$$
\text { Rasio Total Hutang }=\frac{486 \cdot 825}{1 \cdot 182 \cdot 772}=0,41
$$


Tahun 2015

$$
\text { Rasio Total Hutang }=\frac{911.469}{1.517 .789}=0,60
$$

Tahun 2016

$$
\text { Rasio Total Hutang }=\frac{973.694}{1.476 .889}=0,66
$$

Tahun 2017

$$
\text { Rasio Total Hutang }=\frac{2.057 .237}{1.739 .486}=1,18
$$

Tabel 4. Rasio Total Hutang PT. Nippon Indosari Corpindo Tbk (ROTI)

\begin{tabular}{cccc}
\hline Tahun & Arus Kas Operasi & Total Hutang & \% \\
\hline 2014 & 486.825 & 1.182 .772 & 0,41 \\
2015 & 911.469 & 1.517 .789 & 0,60 \\
2016 & 973.694 & 1.476 .889 & 0,66 \\
2017 & 2.057 .237 & 1.739 .486 & 1,18 \\
\hline
\end{tabular}

Sumber: Data Olahan, 2018

$$
\text { Rasio Arus Kas terhadap Laba Bersih }=\frac{\text { Arus Kas Operasi }}{\text { Laba Bersih }}
$$

Tahun 2014

$$
\text { Rasio Arus Kas terhadap Laba Bersih }=\frac{1.149 .556}{283.361}=4,05
$$

Tahun 2015

$$
\text { Rasio Arus Kas terhadap Laba Bersih }=\frac{1.674 .981}{523.100}=3,20
$$

Tahun 2016

$$
\text { Rasio Arus Kas terhadap Laba Bersih }=\frac{2.422 .787}{709.826}=3,41
$$

Tahun 2017

$$
\text { Rasio Arus Kas terhadap Laba Bersih }=\frac{3.044 .536}{711.681}=4,28
$$

Tabel 5. Rasio Arus Kas Terhadap Laba Bersih PT. Ultra Jaya Milk Industry \& Trading Company Tbk (ULTJ)

\begin{tabular}{cccc}
\hline Tahun & Arus Kas Operasi & Laba Bersih & \% \\
\hline 2014 & 1.149 .556 & 283.361 & 4,05 \\
2015 & 1.674 .981 & 523.100 & 3,20 \\
2016 & 2.422 .787 & 709.826 & 3,41 \\
2017 & 3.044 .536 & 711.681 & 4,28 \\
\hline
\end{tabular}

Sumber: Data Olahan 2018 


\section{KESIMPULAN DAN SARAN}

\subsection{Kesimpulan}

Dari hasil analisis rasio laporan arus kas yang telah dilakukan, berikut adalah kesimpulan hasil kinerja dari perusahaan-perusahaan makanan dan minuman selama kurun waktu 4 tahun, yaitu dari tahun 2014-2017. Dalam perhitungan rasio laporan arus kas pada perusahaan-perusahaan makanan dan minuman yaitu PT. Tiga Pilar Sejahtera Food Tbk, PT. Delta Djakarta Tbk, PT. Mayora Indah Tbk, PT. Nippon Indosari Corpindo Tbk, PT. UltraJaya Milk Industry \& Trading Company Tbk, PT. Indofood Sukses Makmur Tbk. Ditemukan bahwa rata-rata dengan tingkat perputaran dari hasil perhitungan seluruh rasio laporan arus kas yang paling tinggi adalah PT. Ultra Jaya Milk Industry \& Trading Company Tbk, di mana terlihat dari seluruh hasil perhitungan rasio laporan arus kas yang menunjukkan perputaran dan presentase dari PT. Ultra Jaya Milk Industry \& Trading Company Tbk. kemudian yang memiliki perputaran dari hasil perhitungan seluruh rasio laporan arus kas yang paling rendah adalah PT. Indofood Sukses Makmur Tbk, di mana dari hasil perhitungan rasio laporan arus kas, rata-rata perputaran yang dihasilkan oleh PT. Indofood Sukses Makmur Tbk adalah yang paling rendah di antara perusahaan-perusahaan makanan dan minuman lainnya yang diteliti dalam penelitian ini.

\subsection{Saran}

Perusahaan harus memperhatikan kinerjanya, di mana perusahaan harus mengfokuskan aktivitas dalam upaya meningkatkan arus kas operasi, untuk itu sebaiknya perusahaan-perusahaan makanan dan minuman mengurangi jumlah hutang, agar di kemudian hari kinerja perusahaan bisa lebih baik. Karena kemampuan perusahaan dalam menutupi biaya bunga belum maksimal maka perusahaan sebaiknya lebih meningkatkan lagi arus kas operasi dari perusahaan, jika perusahaan memiliki arus kas operasi yang meningkat tentu perusahaan mampu menutupi biaya bunga dan menghasilkan kinerja yang baik serta peningkatan dalam mendapatkan laba bersih. Dari hasil tersebut maka perusahaan-perusahaan makanan dan minuman harus lebih meningkatkan kinerja perusahaan dengan mengurangi jumlah hutang dan meningkatkan arus kas operasi. Jika perusahaan lebih meningkatkan hal tersebut dan berusaha memperbaiki masalah-masalah tersebut, maka pasti pada tahun selanjutnya kinerja perusahaan akan jauh lebih baik.

\section{DAFTAR PUSTAKA}

Bursa Efek Indonesia. www.idx.go.id.

Dwi. D. Prastowo. 2015. Analisis Laporan Keuangan. Yogyakarta: UPP STIM YKPN.

Hanafi, Dr. Mahmud M, Prof. Dr. Abdul Halim. 2016. Analisis Laporan Keuangan Edisi Kelima .Yogyakarta: UPP STIM YKN.

Hans Kartikahadi,dkk. 2014. Akuntansi Keuangan Berdasarkan SAK BerbasisIFRS Buku 1. Jakarta : Salemba Empat.

Hery. 2016. Analisis Laporan Keuangan. Jakarta: Grasindo.

Ikatan Akuntansi Indonesia, 2015, Pernyataan Standar Akuntansi Keuangan.

Kasmir. 2014 Analisis Laporan Keuangan. Edisi Pertama. Cetakan Ketujuh. Jakarta : PT. RajaGrafindo Perseda.

Rudianto. 2013. Akuntansi Manajemen: Informasi untuk Pengambilan Keputusan Strategis, Jakarta: Erlangga.

Subramanyam 2017. Analisis Laporan Keuangan financial Statement Analysis. Jakarta: Salemba Empat.

Sofyan Syarfri Harapan. 2013. Analisis Kritis Laporan Keuangan. PT. Raja Grafindo Persada Jakarta. 
Sugiyono. 2015. Metode Penelitian Kuantitatif Kualitatif R\&B. Bandung: Alfabeta. Warren et al. 2014. Accounting Indonesia Adaptation. Jakarta. Salemba Empat.

Warren et all. 2015. Pengantar Akuntansi. Jakarta: Salemba Empat. 